Volume: 10 | Issue: 01| Jan. - March| 2021

EISSN: 2706-7939 ISSN: 2077-4508

DOI: 10.36632/ije/2021.10.1.1

Journal homepage: www.curresweb.com

Pages: 1-14

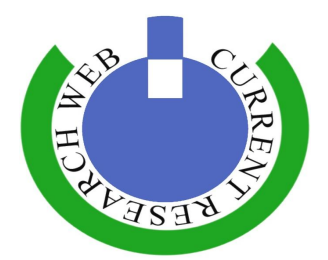

\title{
Heavy Metals in Edible Fruits: A Review
}

${ }^{1}$ Igwe P.U., and ${ }^{2}$ Ezekwesili J.O

Department of Environmental Management, Chukwuemeka Odumegwu Ojukwu University, P.M.B 02, Uli, Anambra State, Nigeria

Received: 10 October 2020

Accepted: 30 December 2020 Published: 15 January 2021

\begin{abstract}
Heavy metals are among the major contaminants of edible fruits and pose a potential health risk to both humans and animals. This paper, therefore, reviewed existing literature on the impact of heavy metals on edible fruits. The method used is a review of academic journal/articles, conference papers, internet materials, textbooks and publicly available materials on some heavy metals in edible fruits. The results of this study indicated that previous authors whose works were reviewed have a convergent view that food safety and security, and human health are inextricably linked and that polluted water, and bad practice in post harvesting handling of the fruit products with disregard to the food safety guidelines, and the physical market environments in these locations surrounded by a heavy urban pollution deposition exacerbate contamination levels of fruit samples and also that crops grown in polluted and degraded environmental conditions in the peri-urban (or urban fringe) zone are subjected to further pollution from vehicles and industries during marketing. Recommendations of this study include: (1) the public should be enlightened on the need for fruits to be properly washed before consumption; (2) government and other responsible food agencies should conduct a yearly monitoring program for heavy metals in foodstuffs in order to prevent their contamination and ensure human safety; and (3) food vendors should be educated on the need to properly cover their goods to avoid being contaminated.
\end{abstract}

Keywords: contamination; edible fruits, food security, heavy metals.

\section{Introduction}

Food safety is a major public concern worldwide. During the past decades, the increasing demands for food safety have stimulated research regarding the risk associated with the consumption of food products contaminated by heavy metals, pesticides and/or toxins (D'Mello, 2003; Aydinalp and Marinova, 2012). Heavy metal pollution has spread broadly over the globe, threatening the environment and posing serious health hazards to humans (Prabhat et al., 2019). According to United Nations- Habitat (2004), the root causes of this problem are generally held to be the rapid pace of urbanization, land use changes, and industrialization, especially in developing countries with extremely high populations.

Advancement in technology has challenged the integrity of the environment with discharge of effluents containing heavy metals (Fulekar et al., 2009). Prabhat et al. (2019) reported that wastewater, treated effluent, and sludge contaminated with heavy metals have frequently been used as low-cost sources of irrigation in parts of Asia and Africa, which has caused food quality, and hence health to deteriorate, they further stated that both highly populated countries (e.g., India and China) and underdeveloped countries (e.g., Nigeria and Zambia) have soil crop subsystems affected by wastewater irrigation and sludge amendment patterns, with food safety and ecotoxicology consequences. Likewise in India, long-term wastewater irrigation has been shown to contaminate food crops with heavy metals (concomitantly changing the physiology and biochemistry of crop plants) and pose health hazards (Ghosh et al., 2012; Chabukdhara et al., 2016).

Corresponding Author: Igwe, P.U., Department of Environmental Management, Chukwuemeka Odumegwu Ojukwu University, P.M.B 02, Uli, Anambra State, Nigeria.

E-mail: greenscenarioservices2100@gmail.com 
China has also focused intensively on ecotoxicological, environmental and food safety because of its extremely high population and need to expand farmlands as a result of rapid industrialization, (especially mining and smelting) and urbanization (Song et al., 2015; Zhang et al., 2015). According to a survey of food safety and human health concerns (regarding heavy metal contamination), $10 \%$ of Chinese territory is contaminated with Cadmium (7.75\%) as the highest contribution), Mercury, Copper, Nickel, and Chromium (the lowest contribution), as a result, several case studies in China were carried out to describe the health risks caused by heavy metal contamination of food crops, especially cereals such as rice, as a result of waste water irrigation (Chang et al., 2014).

Interestingly, unlike in Asia and Africa, the sources of heavy metals in American, European, and Oceanic countries are usually modern intensive agricultural practices, for example, extensive case studies of food crop samples from North and South America have found that the metal concentrations are attributable to the use of $\mathrm{Cu}$-based fungicides and fertilizers in agriculture and particulate matter originating from vehicles and industrial sites (França et al., 2017; McBride et al., 2014). Gonzalez-Martin (2018) opined that the presence of heavy metals in industrially processed foodstuffs/pharmaceuticals were noted in several developed countries of these regions (e.g. Spain, Belgium, England, and USA) which may impose serious human health risks.

According to Mintah et al., (2012), a fruit is the edible and fleshy seed-associated structures of certain plants, which could be sweet such as apples, oranges, grapes, strawberries, juniper berries and bananas or non-sweet such as lemon and olivesin their raw forms. Benefits obtainable from consumption of fruits are greater life span (Bellavia et al., 2013), improved mental health (Conner et al., 2017), better cardiovascular health (Oyebode et al., 2014), reduced risks of some cancers (Boffetta et al., 2010) and weight management (Rolls et al., 2004) among others. In the USA, lower risk of obesity was observed among healthy middle aged women who consume fruits ( $\mathrm{He}$ et al., 2004). Specifically, fruits contain sufficient potassium, which are needed to reduce the effect of bone loss and occurrence of kidney stones (Mintah et al. 2012). According to them, fruits assist in proper functioning of the brain as it stimulates the memory recall and supplies the human body with fibre needed for a healthy digestive system. They also asserted that fruits are also rich in dietary nutrients such as potassium, antioxidants and folic acid and that consumption of fruits guarantees optimum health, gives instant energy to the body and provides vitamins and minerals that are beneficial to body functioning.

Despite the benefits of fruit consumption on human health, heavy metal contents in fruits can be toxic when they exceed the recommended health levels or when they bio-accumulate in the body over a long period (Orisakwe et al., 2012). Heavy metals are not biodegradable, have long biological half- lives and have the potential for accumulation in the different body organs leading to unwanted effects (Singh et al., 2010; Nabulo et al., 2011). Most heavy metals are extremely toxic, and because of their solubility in water, contamination may readily reach toxic levels (Arora et al., 2008). Food chain contamination is one of the most important pathways for the entry of these toxic pollutants into the human body (Wang et al., 2011; Harmanescu et al., 2011). Other than water and soil, foods may also be contaminated with trace metals due to increased usage of chemicals, sprays, preservatives, industrialization, mining activities and fertilizers, (Ali et al., 2015).

Although heavy metals occur as natural constituents of the earth crust, they are mostly considered persistent environmental contaminants since they cannot be degraded or destroyed. Hence, they can enter the body system through food, air and water (Koleayo et al., 2017). These bio-accumulations could be over a period of time due to their long half-lives, the potential for accumulation in the different organs of the body thus leading to unwanted side effects (Lenntech, 2004; Ming-Ho, 2005; Aderinola et al., 2009). Lead (Pb), cadmium (Cd), chromium (Cr), nickel $(\mathrm{Ni})$, copper $(\mathrm{Cu})$ and many other heavy metals are potentially toxic to humans and are widely dispersed in the environment (Morais et al., 2012). The diverse and emerging issues of food security have become a global concern, particularly their inextricable association with human health (Säumel et al., 2016).

\subsection{Statement of the Problem}

The ingestion of fruits contaminated with heavy metals causes serious human health issues, 
such as gastrointestinal cancer, fragile immunological mechanisms, mental growth retardation, and malnutrition (Dickin et al., 2018). Heavy metals can accumulate in human bones or fatty tissues through dietary intake, thereby leading to the depletion of essential nutrients and weakened immunological defenses. Certain heavy metals (e.g., Aluminium, Cadmium and Lead) are further suspected to cause intrauterine growth retardation (Rai, 2018).

Lead contamination adversely affects mental growth, causing neurological and cardiovascular diseases in humans, especially children (Navas-Acien et al., 2007), According to them, certain heavy metals, especially Lead and Cadmuim, have carcinogenic effects and can also lead to bone fractures and malformation, cardiovascular complications, kidney dysfunction, hypertension, and other serious diseases of the liver, lung, nervous system, and immune system (El-Kady and Abdel-Wahhab, 2018). Excessive levels of arsenic in soil, food crops, and groundwater can cause cancer, dermal problems and respiratory complications.

Excess zinc levels in the human body can affect the concentration level and disturb the immune system (Zhou, 2016). Likewise, excess copper intake can induce liver damage and other gastric related problems in humans (Gaetke and Chow, 2003; Rahman et al., 2014). According to the United State Environmental Protection Agency (USEPA) (2000), heavy metals (e.g., chromium, copper, and zinc) in soil can cause non carcinogenic human health hazards such as neurologic complications, headaches, and liver disease.

In general, heavy metal contaminations threaten agriculture and other food sources for human population, which has led to poor vegetation growth and lower plant resistance against forests pests (Ene et al., 2009). Decreased sperm count in men, spontaneous abortions in women, cardiovascular and kidney diseases are associated with high lead exposure (Hertz-Picciotto, 2000). Cadmium intake above recommended level is associated with renal, prostrate and ovarian cancers (Satarug et al., 2011). High level of nickel may cause nervous system disorder, decreased intellectual capacity, zinc or iron deficiency as well as enzymatic malfunctioning (Jarup, 2003). It is well known that copper toxicity induces iron deficiency, lipid peroxidation and destruction of membranes (Zaidi et al., 2005). It is therefore crucial to determine the concentrations of metals present in food as a practical step for effective risk assessment.

\subsection{Objective of the Study} fruits.

The objective of this study is to review studies on the assessment of heavy metals in edible

\section{Conceptual Framework: Sustainable Development}

This research is based on the concept of sustainable development. Morelli and Greenwood, (2010) saw sustainable development as meeting the resources and services needs for current and future generations without compromising the health of the ecosystems and more specifically as a condition of balance, residence and interconnection that allows human society to satisfy its needs while neither exceeding the capacity of its ecosystems to continue to regenerate the services necessary to meet those needs nor by our actions diminishing biological diversity. World Conference on Environment and Development (WCED) (1987) stated that sustainable development is development that meets the needs of the present without compromising the ability of future generations to meet their own needs. This research sets to review studies on some heavy metals in edible fruits so as to build in sustainability into the management of the impact of heavy metals in edible fruits on human health and the environment.

\section{Method}

Data used for this study is derived from published works including academic articles, journals, conference papers, textbooks and internet materials. The researchers gathered 59 materials for the research but summarized the characteristics of 10 that centered more on determination of the levels of heavy metals in edible fruits. This enabled the researchers to make a synthesis of various researchers' views on the occurrence of heavy metals in edible fruits and their health impact. 


\section{Review of Related Literature}

Akinola and Adenuga (2008) studied the levels of some heavy metals in African pear (dacryodesedulis) marketed in Lagos metropolis, Nigeria and were of the view that the washed samples revealed that metal pollutants can exist as superficial contaminants on the surface of the fruit wall which is the edible portion and that if the fruit is thoroughly washed, it may increase its safety for dietary consumption. They also opined that the presence of these heavy metals in the fruits confirms that quite a large amount of atmospheric emissions from machines or vehicles might have deposited on the fruits

\subsection{Statement of the Problem}

The ingestion of fruits contaminated with heavy metals causes serious human health issues, such as gastrointestinal cancer, fragile immunological mechanisms, mental growth retardation, and malnutrition (Dickin et al., 2018). Heavy metals can accumulate in human bones or fatty tissues through dietary intake, thereby leading to the depletion of essential nutrients and weakened during transportation and/or where they were displayed for sale in the open markets along the roadside and that these gaseous emissions contain lead which comes from leaded gasoline which is still very much in use in Nigeria. They further reported that the unwashed samples contained higher concentrations of the heavy metals than the washed samples. According to them a high percentage of lead and cadmium was washed off from the fruit wall and that more than 50 to over 80 percent of lead and more than 30 to over 60 percent of cadmium were washed off from the fruit wall. In addition, they noted that this is an indication that quite a large amount of atmospheric emissions from machines and vehicles deposit only on the plants as artificial contaminants and that the usual practice of thoroughly washing vegetables and fruits before consumption is indeed good and can help remove a substantial quantity of contaminants from getting to the body of their consumers.

Seyed and Somashekar (2008) did a research on heavy metals and safety of fresh fruits in Bangalore city, India-a case study and reported that the increasing trends in food contamination in urban areas are largely attributed to the polluted environment in urban agriculture, contaminated food transport and supply chains, poor market sanitary conditions, and the use of contaminated or waste water for irrigation purposes. According to them, urban consumers are at greater risk of purchasing fresh fruits with high levels of heavy metals beyond the legally permissible limits as defined by the Indian Prevention of Food Adulteration Act, 1954. They also asserted that the crops were often grown in polluted and degraded environmental conditions in agricultural zones and are subject to further pollution from vehicles and industries during packaging, supplying and marketing. They went further to argue that most farmlands were heavily irrigated using mechanized pumps, and although this has helped increase agricultural production, the water economy plays a critical part in determining the quality of water being used and that the problem arises when that irrigation water comes from sewage and industrial fed lakes, rivers, or contaminated ground water. They further argued that the use of polluted water, bad practice in post harvesting handling of the fruit products with disregard to the food safety guidelines, and the physical market environments in these locations surrounded by a heavy urban pollution deposition may have exacerbated contamination levels of these fruit samples.

Debopam et al. (2010) performed a study on heavy metal contamination in fruits and vegetables in two districts of West Bengal, India and reported that citizens have a right to get safe food and to be ensured that the vegetables available to them are not contaminated beyond acceptable safe limits. They also asserted that heavy metal depositions are associated with a wide range of sources such as small scale industries (including battery production, metal products, metal smelting and cable coating industries); brick kilns; vehicular emissions; re-suspended road dust and diesel generator sets. They further stated that vegetable crops are often grown in polluted and degraded environmental conditions in the peri-urban (or urban fringe) zone and are subjected to further pollution from vehicles and industries during marketing. According to them, they are also a significant cause for concern regarding contamination; it is a fact that vegetable production also has a major role to play in supporting the livelihoods of the poor and these people often have little choice but to farm in polluted areas and have limited access to advice and support. In their opinion, this investigation highlights the increased danger of growing vegetables in the vicinity of highway 
and industrial area. They recommended that regular survey of heavy metals should be done on all food commodities in order to evaluate whether any health risks from heavy metal exposure do exist, to assume food safety and to protect the end users from food that might injure their health.

Aweng et al. (2011) did a study on heavy metals concentration of irrigation water, soils and fruit vegetables in Kota Bharu area, Kelantan, Malaysia and stated that high concentrations of heavy metals in soil and irrigation water led to the accumulation of heavy metals in vegetables. They also reported that heavy metal concentrations varied among the test vegetables, which reflect the differences in their uptake capabilities and their further translocation to edible portion of the plants. They argued that irrigation water was a dominant factor to determine the concentrations of heavy metals in vegetables compared to soil because irrigation water normally led to the accumulation of heavy metals in soil and consequently into vegetables and that based on the results, boron was found to be the highest in irrigation water as well as in vegetables but not in soil.

Crentsil et al., (2011) carried out a study on assessing potential dietary intake of heavy metals in some selected fruits and vegetables from Ghanaian markets and opined that heavy metals are environmentally hazardous and many developed and developing countries have been continuing to monitor the trends of residues in fruits and vegetables but maximum residue limit (MRL) for heavy metal in foodstuffs is currently not in force in most countries. According to them, this indicates that the present monitoring program that has been conducted only for heavy metals in fruits and vegetables is insufficient. They further stated that although heavy metals in fruits and vegetables do not pose any immediate risk to human health so far, but continued consumption of such fruit and vegetables even with moderate contamination level can accumulate in the receptors body and may prove fatal for human population in the long term.

Elbagermi et al. (2012) conducted a study on monitoring of heavy metal contents in fruits and vegetables collected from production and market sites in the Misurata area of Libya and stated that the fruits and vegetables collected from chosen production and market sites in their study area contained measured heavy metal contents within the safe limits prescribed by the World Health Organization in 1999. According to them, this is an important result as human health is directly affected by ingestion of fruits and vegetables; they recommended that the biomonitoring of trace elements in fleshy fruits needs to be continued because these are the main sources of food for humans in many parts of the world.

Mohamed and Khairia (2012) conducted a study on the assessment of some heavy metals in vegetables, cereals and fruits in Saudi Arabian markets and were of the view that atmospheric depositions and marketing systems of vegetables play a significant role in elevating the levels of heavy metals in vegetables having potential health hazards to consumers of locally produced foodstuffs. According to them, high concentrations of heavy metals in different parts of the vegetables might be related to their concentration in the polluted air with industrialactivities.

In their study on minerals and heavy metals concentration in selected tropical fruits of Bangladesh, Sajib, Hoque, Yeasmin and Khatun (2014) were of the view that fruits and vegetables are specially valued in human diet as these contain micronutrients, fiber, potassium, vitamin C, which work as antioxidants within the body as well as bio-functional components. According to them, tropical fruits could be potentially used in alleviating micronutrients deficiency especially for the rural populace as a potent source of minerals. They also stated that the daily intake of heavy metals such as arsenic, cadmium, lead, mercury and chromium through fresh fruits may not constitute a health hazard for consumers because the concentrations were below than the recommended daily intake of these metals but that consumers should be aware of taking fresh fruit as these amounts can be harmful if the fruits are taken in large quantities. They recommended that the use of adulterants such as oxytocin sachharin, wax (paraffin), copper sulphate and calcium carbidein fruits must be strictly prohibited in order to prevent excessive build-up of these metals in the human food chain, considering its hazardous aspects; it must be strictly monitored and controlled. They further argued that it is not solely the responsibility of the government; the people must also become aware and avoid consuming contaminated fruits.

Chigozie and Maximilian (2017) conducted a study on a market basket survey of horticultural fruits for arsenic and trace metal contamination in southeast Nigeria and potential health risk implications and opined that elevated arsenic and trace metal contamination of the terrestrial food chain represents one of the most significant environmental risk exposures for human populations 
in developing countries. They also noted that metalloid and metal contamination in horticultural crop produce such as fruit is a public health concern in Nigeria. According to them, local fruits are cheap sources of vitamins and minerals for the resident population and pose an important dietary threat of metal (loid) toxicity through consumption. They further noted that the significant concentrations of $\mathrm{As}$ and $\mathrm{Hg}$ in the examined fruits indicate a potential public health threat and that efforts are needed to initiate and sustain continued monitoring of trace elements in fruits and food sold to consumers due to variation in contaminating sources to ensure food safety.

In his study on analysis of heavy metal levels in some edible fruits from selected markets in Ethiopia, Wodaje (2017) opined that the relatively high level of heavy metals in samples collected from Addis Ababa market may be due to the fact that samples in this area comes from different regions of the country. He noted that the source of production of the fruits is unknown and the other reason may be contamination at the time of transportation. He recommended that appropriate precautions should be taken at the time of transportation and regular monitoring of heavy metals in fruits and other food items should be performed in order to prevent excessive build-up of these metals in the human food chain and to avoid consumption of contaminated fruit foodstuffs.

Koleayo, Kelechi, Olutunde and Olapeju (2017) assessed the nutritional composition and heavy metal content of selected fruits in Nigeria and opined that despite the nutritional benefits obtained from fruit consumption, the presence concerns as these affect human health. According to them, the human body can easily be contaminated by heavy metals such as $\mathrm{Ni}, \mathrm{Cd}, \mathrm{Cr}, \mathrm{Pb}$, and $\mathrm{Cu}$ through dietary exposure or by exposition to heavy metal contaminated environments. They also stated that increased concentration of heavy metals is associated with the etiology of a number of diseases, especially cardiovascular, renal and neurological disorders. They reported that the apples sampled from different locations had nickel and chromium levels above the WHO permissible limits and that excess uptake of chromium and nickel may cause skin rashes, stomach upset, kidney and liver damage, lung cancer and ultimately death. They further recommended that there is a need for continuity of heavy metals inspection in agricultural products so as to prevent contamination and secure human safety.

Prabhat et al. (2019) reviewed heavy metals in food crops: health risks, fate, mechanisms, and management and reported that adverse effects of unexpected contaminants on crop quality have threatened both food security and human health. According to them, environmental contaminants, food safety and security, and human health are inextricably linked. They also reported that the sources of heavy metals in food crops vary in the developing and developed world, and that the use of industrial effluents and sewage sludge as fertilizers are the primary contamination sources in soil-crop systems in developed countries while in developing countries, irrigation with inadequately treated effluent or sludge is the main contamination source for food crops. They recommended that eco-feasible technological innovations such as nano-tools and the awareness of farmers could boost local economies and livelihoods with certain financial guarantees.

All the authors whose works were summarized in Table 1: Seyed and Somashekar (2008); Debopam et al., (2010); Crentsil et al., (2011); Elbagermi et al., (2012); Mohamed and Khairia (2012); Sajib et al., (2014); Chigozie and Maximilian (2017); Koleayo et al. (2017); Wodaje (2017); and Prabhat et al. (2019) made use of standard method for obtaining data and information in a research which include laboratory analysisinternet and review of related literature.

The results of the review indicated that heavy metals are among the major contaminants of fruits and poses a potential health risk to both humans and animals. Table 1 summarizes the characteristics of some of the studies reviewed in this research. From the table, Prabhat et al. (2019) and Seyed and Somashekar (2008) have a convergent view that polluted water, bad practice in post harvesting handling of the fruit products with disregard to the food safety guidelines, and the physical market environments in these locations surrounded by a heavy urban pollution deposition might have exacerbated contamination levels of fruit samples.

Debopam et al. (2010) and Seyed and Somashekar (2008) had a unity of opinion that vegetable crops grown in polluted and degraded environmental conditions in the peri-urban (or urban fringe) zone are subjected to further pollution from vehicles and industries during marketing. Mohamed and Khairia (2012) and Debopam et al., (2010) were of the opinion that high concentrations of heavy metals in different parts of the vegetables might be related to their concentration in the polluted air with industrial activities. 
Table.1: Summary of Characteristics of some Studies that described Assessment of some Heavy Metals in Edible Fruits

\begin{tabular}{|c|c|c|c|c|c|c|}
\hline $\mathbf{S} / \mathbf{N}$ & Author(s) & $\begin{array}{l}\text { Topic of } \\
\text { research }\end{array}$ & Method(s) & Result(s) & Recommendation(s) & Conclusion \\
\hline 1 & $\begin{array}{l}\text { Seyed and } \\
\text { Somashekar } \\
(2008)\end{array}$ & $\begin{array}{c}\text { Heavy Metals and } \\
\text { Safety of Fresh Fruits in } \\
\text { Bangalore City, India } \\
\text {-A case study }\end{array}$ & $\begin{array}{l}\text { Laboratory } \\
\text { analysis }\end{array}$ & $\begin{array}{l}\text { Use of polluted water, bad } \\
\text { practice in post harvesting } \\
\text { handling of the fruit products } \\
\text { with disregard to the food safety } \\
\text { guidelines, and the physical } \\
\text { market environments in these } \\
\text { locations surrounded by a heavy } \\
\text { urban pollution deposition might } \\
\text { have exacerbated contamination } \\
\text { levels of fruit samples. }\end{array}$ & $\begin{array}{l}\text { Improve sanitary conditions } \\
\text { for the city food markets; and } \\
\text { increase awareness in } \\
\text { consumers and policy makers } \\
\text { on the dangers of heavy } \\
\text { metal contamination in the } \\
\text { food intake. }\end{array}$ & $\begin{array}{l}\text { The study concluded that } \\
\text { urban consumers are at } \\
\text { greater risk of purchasing } \\
\text { fresh fruits with high levels } \\
\text { of heavy metals beyond the } \\
\text { legally permissible limits as } \\
\text { defined by the Indian } \\
\text { Prevention of Food } \\
\text { Adulteration Act, } 1954 \text {. }\end{array}$ \\
\hline 2 & $\begin{array}{c}\text { Debopam et al., } \\
\text { (2010) }\end{array}$ & $\begin{array}{c}\text { Heavy Metal } \\
\text { Contamination in Fruits } \\
\text { and Vegetables } \\
\text { in two Districts of West } \\
\text { Bengal, India }\end{array}$ & $\begin{array}{l}\text { Laboratory } \\
\text { analysis }\end{array}$ & $\begin{array}{l}\text { Vegetable crops grown in } \\
\text { polluted and degraded } \\
\text { environmental conditions in the } \\
\text { peri-urban (or urban fringe) zone } \\
\text { are subjected to further pollution } \\
\text { from vehicles and industries } \\
\text { during marketing. }\end{array}$ & $\begin{array}{l}\text { Awareness to consumers should } \\
\text { be educated about } \\
\text { what they are taking and the } \\
\text { health implication as well as } \\
\text { assist them and the farmers in } \\
\text { taking necessary precautions } \\
\text { towards proper care of their fruits } \\
\text { and vegetables before } \\
\text { consumption. }\end{array}$ & $\begin{array}{l}\text { No soil sample was found to } \\
\text { contain heavy metals above } \\
\text { allowable } \\
\text { concentration, which } \\
\text { shows that contamination } \\
\text { was mainly due to } \\
\text { automobile } \\
\text { exhaust, pesticides } \\
\text { and industrial exhaust. }\end{array}$ \\
\hline 3 & $\begin{array}{l}\text { Crentsil et al., } \\
\text { (2011) }\end{array}$ & $\begin{array}{c}\text { Assessing Potential } \\
\text { Dietary intake of Heavy } \\
\text { Metals } \\
\text { in some Selected Fruits } \\
\text { and } \\
\text { Vegetables from } \\
\text { Ghanaian Markets }\end{array}$ & $\begin{array}{l}\text { Literature review } \\
\text { of materials }\end{array}$ & $\begin{array}{l}\mathrm{Zn} \text { and } \mathrm{Cu} \text { were detected in all } \\
\text { the monitored fruits and } \\
\text { vegetable samples surveyed. }\end{array}$ & $\begin{array}{l}\text { A yearly monitoring program for } \\
\text { heavy metals in foodstuffs is } \\
\text { necessary. }\end{array}$ & $\begin{array}{l}\text { Although heavy metals in } \\
\text { fruits and vegetables do not } \\
\text { pose any immediate risk to } \\
\text { human health so far, but } \\
\text { continues consumption of } \\
\text { such fruit and vegetables } \\
\text { even with moderate } \\
\text { contamination level can } \\
\text { accumulate in the } \\
\text { receptors body and may } \\
\text { prove fatal for human } \\
\text { population in thelong term }\end{array}$ \\
\hline
\end{tabular}




\begin{tabular}{|c|c|c|c|c|c|c|}
\hline 4 & $\begin{array}{c}\text { Elbagermi et al. } \\
\quad(2012)\end{array}$ & $\begin{array}{l}\text { Monitoring of Heavy } \\
\text { Metal Content in Fruits } \\
\text { and Vegetables } \\
\text { Collected from } \\
\text { Production } \\
\text { and Market Sites in the } \\
\text { Misurata Area of Libya }\end{array}$ & $\begin{array}{l}\text { Laboratory } \\
\text { analysis }\end{array}$ & $\begin{array}{l}\text { The highest mean levels of } \mathrm{Pb} \text {, } \\
\mathrm{Cu}, \mathrm{Zn}, \mathrm{Co}, \mathrm{Ni} \text { and } \mathrm{Cd} \text { were } \\
\text { detected in mango, melon, } \\
\text { spinach, banana and mango } \\
\text { fruits, respectively. }\end{array}$ & $\begin{array}{l}\text { Biomonitoring of trace elements } \\
\text { in fleshy fruits needs to be } \\
\text { continued because these are the } \\
\text { main sources of food for humans } \\
\text { in many parts of the world. }\end{array}$ & $\begin{array}{l}\text { The estimated daily intakes } \\
\text { for the heavy metals studied } \\
\text { are below those reported } \\
\text { by the } \\
\text { FAO/WHO. }\end{array}$ \\
\hline 5 & $\begin{array}{l}\text { Mohamed and } \\
\text { Khairia } \\
(2012)\end{array}$ & $\begin{array}{c}\text { Assessment of some } \\
\text { Heavy Metals in } \\
\text { Vegetables, Cereals and } \\
\text { Fruits in Saudi Arabian } \\
\quad \text { Markets }\end{array}$ & $\begin{array}{l}\text { Laboratory } \\
\text { analysis }\end{array}$ & $\begin{array}{l}\text { High concentrations of heavy } \\
\text { metals in different parts of the } \\
\text { vegetables might be related to } \\
\text { their concentration in the } \\
\text { polluted air with industrial } \\
\text { activities. }\end{array}$ & $\begin{array}{l}\text { enhance better coordination in } \\
\text { fresh crops trading system to } \\
\text { improve food safety standards }\end{array}$ & $\begin{array}{l}\text { Atmospheric depositions and } \\
\text { marketing systems of } \\
\text { vegetables play a significant } \\
\text { role in elevating the levels of } \\
\text { heavy metals in vegetables } \\
\text { having potential health } \\
\text { hazards to consumers of } \\
\text { locally produced foodstuffs. }\end{array}$ \\
\hline 6 & $\begin{array}{l}\text { Sajib et al., } \\
\quad(2014)\end{array}$ & $\begin{array}{c}\text { Minerals and Heavy } \\
\text { Metals Concentration in } \\
\text { selected Tropical Fruits } \\
\text { of } \\
\text { Bangladesh }\end{array}$ & $\begin{array}{l}\text { Laboratory } \\
\text { Analysis and } \\
\text { Literature } \\
\text { review of } \\
\text { materials }\end{array}$ & $\begin{array}{l}\text { Chromium was found in almost } \\
\text { all selected fruit varieties except } \\
\text { guava and mango. Cadmium was } \\
\text { found only in Sapodilla, Stone- } \\
\text { apple and in Tamarind fruit, } \\
\text { while mercury was found in } \\
\text { Sapodilla, Stone- apple, } \\
\text { Elephant-apple and in Tamarind } \\
\text { fruit. }\end{array}$ & $\begin{array}{l}\text { It was suggested that the use of } \\
\text { adulterants in fruits must be } \\
\text { strictly prohibited in order to } \\
\text { prevent excessive build-up of } \\
\text { these metals in the human food } \\
\text { chain }\end{array}$ & $\begin{array}{l}\text { The daily intake of arsenic, } \\
\text { cadmium, lead, mercury and } \\
\text { chromium through fresh } \\
\text { fruits may not constitute a } \\
\text { health hazard for consumers } \\
\text { because the values were } \\
\text { below the recommended } \\
\text { daily intake of these metals. } \\
\text { However, these amounts can } \\
\text { be hazardous if the fruits are } \\
\text { taken in large quantities. }\end{array}$ \\
\hline 7 & $\begin{array}{l}\text { Chigozie and } \\
\text { Maximilian } \\
\quad(2017)\end{array}$ & $\begin{array}{c}\text { A Market Basket } \\
\text { Survey of Horticultural } \\
\text { Fruits for Arsenic and } \\
\text { Trace Metal } \\
\text { Contamination in } \\
\text { Southeast Nigeria and } \\
\text { Potential } \\
\text { Health Risk } \\
\text { Implications }\end{array}$ & $\begin{array}{l}\text { Laboratory } \\
\text { Analysis }\end{array}$ & $\begin{array}{l}\text { The examined fruits had higher } \\
\text { total As and } \mathrm{Hg} \text { concentrations, } \\
\text { and that significant } \\
\text { concentrations of As and } \mathrm{Hg} \text { in } \\
\text { the examined fruits indicate a } \\
\text { potential public health. }\end{array}$ & $\begin{array}{l}\text { Food intake assessment methods } \\
\text { based on a more comprehensive } \\
\text { determination of food types and } \\
\text { consumption patterns of the local } \\
\text { population need to be } \\
\text { implemented and individual } \\
\text { consumption data generated to } \\
\text { facilitate the risk assessments of } \\
\text { metals. }\end{array}$ & $\begin{array}{l}\text { Although the present } \\
\text { investigation did not } \\
\text { examine the effects of } \\
\text { adulterants on imported } \\
\text { apples, the screening system } \\
\text { should be expanded to } \\
\text { monitor and control their use } \\
\text { on fruits, as there is evidence } \\
\text { of adverse health } \\
\text { effects associated with } \\
\text { adulterants in the food } \\
\text { industry. }\end{array}$ \\
\hline
\end{tabular}




\begin{tabular}{|c|c|c|c|c|c|c|}
\hline 8 & $\begin{array}{l}\text { Koleayo et al., } \\
\quad \text { (2017) }\end{array}$ & $\begin{array}{l}\text { Nutritional Composition } \\
\text { and Heavy Metal } \\
\text { content of selected } \\
\text { Fruits in Nigeria }\end{array}$ & $\begin{array}{l}\text { Laboratory } \\
\text { analysis }\end{array}$ & $\begin{array}{l}\text { Apples sampled for different } \\
\text { locations had nickel and } \\
\text { chromium levels above the } \\
\text { WHO permissible limits and } \\
\text { that excess uptake of } \\
\text { chromium and nickel may } \\
\text { cause skin rashes, stomach } \\
\text { upset, kidney and liver } \\
\text { damage, lung cancer and } \\
\text { ultimately death. }\end{array}$ & $\begin{array}{l}\text { There is a need for continuity } \\
\text { of heavy metals inspection in } \\
\text { agricultural products so as to } \\
\text { prevent contamination and } \\
\text { secure human safety. }\end{array}$ & $\begin{array}{l}\text { Excess uptake of } \\
\text { chromium and nickel may } \\
\text { cause skin rashes, stomach } \\
\text { upset, kidney and liver } \\
\text { damage, lung cancer and } \\
\text { ultimately death. }\end{array}$ \\
\hline 9 & $\begin{array}{l}\text { Wodaje } \\
\text { (2017) }\end{array}$ & $\begin{array}{l}\text { Analysis of Heavy } \\
\text { Metal Levels } \\
\text { in some Edible Fruits } \\
\text { from selected } \\
\text { Markets in Ethiopia }\end{array}$ & $\begin{array}{l}\text { Laboratory } \\
\text { analysis }\end{array}$ & $\begin{array}{l}\text { There was a relatively higher } \\
\text { concentration of heavy metals in } \\
\text { fruit samples procured from } \\
\text { Addis Ababa market than } \\
\text { Awassa market while cadmium } \\
\text { concentrations in both markets } \\
\text { were below the detection limit. }\end{array}$ & $\begin{array}{l}\text { Treated effluent or sludge is the } \\
\text { main contamination source for } \\
\text { food crops. }\end{array}$ & $\begin{array}{l}\text { Appropriate precautions } \\
\text { should be taken at the time of } \\
\text { transportation and regular } \\
\text { monitoring of heavy metals } \\
\text { in fruits and other food items } \\
\text { should be performed in order } \\
\text { to prevent excessive build-up } \\
\text { of these metals in the human } \\
\text { food chain and to avoid } \\
\text { consumption of } \\
\text { contaminated fruit food stuff }\end{array}$ \\
\hline 10 & $\begin{array}{l}\text { Prabhat et al., } \\
\quad \text { (2019) }\end{array}$ & $\begin{array}{l}\text { Heavy Metals in Food } \\
\text { Crops: Health Risks, } \\
\text { Fate, Mechanisms, and } \\
\text { Management }\end{array}$ & $\begin{array}{c}\text { Literature review } \\
\text { of materials and } \\
\text { Internet }\end{array}$ & $\begin{array}{l}\text { The use of industrial effluents } \\
\text { and sewage sludge as fertilizers } \\
\text { are the primary contamination } \\
\text { sources in soil-crop systems in } \\
\text { developed countries. While in } \\
\text { developing countries, irrigation } \\
\text { with inadequately treated } \\
\text { effluent or sludge is the main } \\
\text { contamination source for food } \\
\text { crops. }\end{array}$ & $\begin{array}{l}\text { Rapid and accurate mapping of } \\
\text { soil pollution is needed to } \\
\text { prevent the transfer of metallic } \\
\text { contaminants into the food chain } \\
\text { and to formulate suitable } \\
\text { remediation strategies. }\end{array}$ & $\begin{array}{l}\text { Environmental } \\
\text { contaminants, food safety } \\
\text { and security, and human } \\
\text { health are inextricably } \\
\text { linked. }\end{array}$ \\
\hline
\end{tabular}

Source: Researchers' design, 2019, adapted from Igwe et al. (2017). 
Sajib et al. (2014) and Debopam et al. (2010) had a unity of opinion that in almost all the collected samples, cadmium and chromium in some of the samples exceeded the allowable limit. Koleayo et al. (2017) and Sajib et al., (2014) were of the opinion that excess uptake of chromium and nickel may cause skin rashes, stomach upset, kidney and liver damage, lung cancer and ultimately death.

Generally, the authors concurred that environmental contaminants, food safety and security, and human health are inextricably linked. They also reported that the adverse effects of unexpected contaminants on crop quality have threatened both food security and human health. Thus, all the authors have a convergent view that despite the nutritional benefits obtained from fruit consumption, the presence of heavy metals accompanying it from the environment draws scientific concerns as these affect human health.

\section{Recommendations}

From the results of the review, the following recommendations are made

i. The public should be enlightened on the needs for fruits to be properly washed before consumption.

ii. Government and other responsible food agencies to conduct a yearly monitoring program for heavy metals in foodstuffs in order to prevent their contamination and ensure human safety.

iii. Food vendors should be educated on the need to properly cover their goods to avoid being contaminated

iv. Appropriate precautions should be taken at the time of transportation and regular monitoring of heavy metals in fruits and other food items should be performed in order to prevent excessive build-up of these metals in the human food chain and to avoid consumption of contaminated fruit food stuffs.

v. The use of adulterants must be strictly monitored and controlled by the government.

\section{Conclusion}

More recent findings globally have linked excessive bioaccumulation of heavy metals to numerous health abnormalities such as some forms of cancers, decreased intellectual capacity, decreased reproductive health and cardiovascular diseases. The above review reveals the high exposure of fresh fruit products to heavy metals, based on the review, crops are often grown in polluted and degraded environmental conditions in agricultural zones and are subject to further pollution from vehicles and industries during packaging, supplying and marketing. Another factor is the fact that most farmlands nowadays are heavily irrigated using mechanized pumps; and although this has helped increase agricultural production, the problem arises when that irrigation water comes from sewage and industrial fed lakes, rivers, or contaminated ground water. High concentrations of heavy metals in soil and irrigation water led to the accumulation of heavy metals in vegetables. Considering the hazardous nature of heavy metals, a yearly monitoring program for heavy metals in foodstuffs is necessary. This is not solely the responsibility of the government; the people must also become aware and avoid consuming contaminated fruits.

\section{Acknowledgement}

We appreciate the grace and empowerment of God Almighty who has been our source of strength from beginning to completion of this work. We also commend the effort of the relations, friends and well- wishers of the authors who contributed both financially and otherwise for making this review a success. Our gratitude extends to the Vice chancellor and the entire stakeholders of Chukwuemeka Odumegwu Ojukwu University, Uli, Anambra State, Nigeria for providing a platform for the study of Environmental Management. To all the lecturers, head of department and dean of the faculty of Environmental Sciences, we appreciate their collective efforts in making sure that the goal of environmental management is achieved in the institution. I am highly indebted to the chief author, Mr. Igwe, P.U. for his tireless effort towards an extensive research on the materials used for the review. We cannot fail to commend and appreciate the works of various authors used for the review. Finally, we thank the entire students of Environmental Management especially her final year students for their support throughout the review. 


\section{References}

Aderinola, O.J., E.O. Clarke, O.M. Olarinmoye, V. Kusemiju and M.A. Anatekhai, 2009. Heavy Metals in Surface Water, Sediments, Fish and Perwinkles of Lagos, Lagoon. AmericanEurasian Journal of Agriculture and Environmental Science, 5(5): 609-617.

Akinola, M.O., and A.A. Adenuga, 2008. Determination of the Levels of some Heavy Metals in African Pear (Dacryodes edulis) Marketed in Lagos Metropolis, Nigeria. J. Appl. Sci. Environ. Manage, 12(1):33 - 37.

Ali, E., E.F. Ayub, S. Nabi, M.L. Ali, A. Malek and S.Sh. Seyedeh, 2015. Assessment of some Heavy Metals in Fruits and Vegetables Collected From Markets in Urmia, Iran, Nt. J Curr Sci., 2250- 1770.

Arora, M., B. Kiran, S. Rani, A. Rani, B. Kaur, and N. Mittal, 2008. Heavy metal Accumulation in Vegetables Irrigated with Water from different Sources. Food Chemistry, 111(4): 811815.

Aweng, E.R., M. Karimah, and O. Suhaimi, 2011. Heavy Metals Concentration of Irrigation Water, Soils and Fruit Vegetables in Kota Bharu Area, Kelantan, Malaysia. Journal of Applied Science in Environmental Sanitation, 6 (4): 463-470.

Aydinalp, C., and S. Marinova, 2012. Concentration of $\mathrm{Cu}$ and $\mathrm{Zn}$ in Some Fruits and Vegetables Grown in North Western Turkey. Bulg. J. Agric Sci., 18(5): 749-751.

Bellavia, A., S.C. Larsson, M. Bottai, A. Wolk, and N. Orsini, 2013. Fruit and vegetable consumption and all-cause mortality: A dose-response analysis. The American Journal of Clinical Nutrition, 98 (2):454-459.

Boffetta, P., E. Couto, J. Wichmann, P. Ferrari, D. Trichopoulos, and H.B. Bueno-de-Mesquita, 2010. Fruit and vegetable intake and overall cancer risk in the European Prospective Investigation into Cancer and Nutrition (EPIC). Journal of the National Cancer Institute, 102 (8):529-537.

Chabukdhara, M., A. Munjal, A.K. Nema, S.K. Gupta, and R.K. Kaushal, 2016. Heavy Metal Contamination in Vegetables Grown around Peri-Urban and Urban-Industrial Clusters in Ghaziabad, India. Hum. Ecol .Risk. Asses, 22(3):736-752.

Chang, C.Y., H.Y. Yu, J.J. Chen, F.B. Li, and H.H. Zhang, 2014. Accumulation of Heavy Metals in Leaf Vegetables from Agricultural Soils and Associated Potential Health Risks in the Pearl River Delta, South China. Environ. Monit. Assess, 186:1547-1560.

Chigozie, D.E., and O.O. Maximilian, 2017. A Market Basket Survey of Horticultural Fruits for Arsenic and Trace Metal Contamination in Southeast Nigeria and Potential Health Risk Implications, Journal of Health \& Pollution, 7:(15).

Conner, T.S., K.L. Brookie, A.C. Carr, L.A. Mainvil, and M.C.M. Vissers, 2017. Let them eat fruit! The effect of fruit and vegetable consumption on psychological well-being in young adults: A randomized controlled trial. Journal. Pone, 12(2):171-206.

Crentsil, K.B., B.K. Archibold, O.T. Anita, D. Dzifa, and B. Nash, 2011. Assessing Potential Dietary Intake of Heavy Metals in some Selected Fruits and Vegetables from Ghanaian Markets. Elixir International Journa, 9:4921-4926.

D'Mello, J.P.F., 2003. Food Safety: Contaminants and Toxins. Wallingford Oxon, UK, Cambridge: CABI Publishing, 480-482p.

Debopam, B., B. Himadri, M. Sibabrata, P. Anju, B. Debabrata, and R. Lalitagauri, 2014. Heavy Metal Contamination in fruits and Vegetables in two Districts of West Bengal, India. Electronic Journal of Environmental, Agricultural and Food Chemistry, 15:4377- 1579.

Dickin, S.K., C.J. Schuster-Wallace, M. Qadir, and K. Pizzacalla, 2016. Areview of health risks and pathways for exposure to waste water use in agriculture. Environ. Health Perspect, 124(7):900- 909.

Elbagermi, M.A., H.G.M. Edwards, and A.I. Alajtal, 2014. Monitoring of Heavy Metal Content in Fruits and Vegetables Collected from Production and Market Sites in the Misurata Area of Libya. International Scholarly Research Network: Analytical Chemistry, 5:827645. 
El-Kady, A.A., and M.A. Abdel-Wahhab, 2018. Occurrence of Trace Metals in Food Stuffs and their Health Impact. Trends Food Sci. Technol., 75:36-45.

Ene, A., A. Boşneaga, and L. Georgescu, 2009. Determination of Heavy Metals in Soils using XRF technique. University of Galati, Faculty of Sciences, Chemistry Department, Romania, $815 \mathrm{p}$.

França, F.C.S.S., and A.M.A. Albuuerque, 2017. Heavy metals deposited in the culture flettuce (Lactuca sativa L.) by the influence of vehicular traffic in Pernambuco, Brazil. Food Chem., 215:171-176.

Fulekar, M., A. Singh, and A.M. Bhaduri, 2009. Genetic Engineering Strategies for Enhancing Phytoremediation of Heavy Metals. African Journal of Biotechnology, 8:529-535.

Gaetke, L.M., and C.K. Chow, 2003. Copper toxicity, oxidative stress, and antioxidant nutrients. Toxicology. 189:147-163.

Ghosh, A.K., M.A. Bhatt, and H.P. Agrawal, 2012. Effect of Long-term Application of Treated Sewage Water on Heavy Metal Accumulation in Vegetables Grown in Northern India. Environ. Monit. Assess, 184: 1025-1036.

Gonzalez-Martin, M.I., 2018. Pesticide residues and heavy metals in commercially processed propolis. Microchem. J., 143:423-429.

Harmanescu, M., L.M. Alda, D.M. Bordean, I. Gogoasa, and I. Gergen, 2011. Heavy Metals Health Risk Assessment for Population via Consumption of Vegetables Grown in Old Mining Area; A Case Study: Banat County. Romania Chem. Cent., J, 5:64.

He, K.F.B., G.A. Hu, J.E. Colditz, W.C. Manson, and S.L. Willett, 2004. Changes in intake of fruits and vegetables in relation to risk of obesity and weight gain among middle-aged women. International Journal of Obesity, 28:1569-1574.

Hertz-Picciotto, I., 2000. The evidence that lead increases the risk for spontaneous abortion. American Journal Industrial Medicine, 38: 300-309.

Igwe, P.U., C.C. Nweze, J.E. Echendu, I.C. Chukwunyere, and N.J. Okonkwo, 2017. Adaptations to Soil Erosion: A Review. International Journal of Advanced Engineering, Management and Science (IJAEMS), 3(12):103-111.

Jarup, L., 2003. Hazards of Heavy Metal Contamination. British Medical Bulletin, 68: 167-182.

Koleayo, O.O., L.N. Kelechi, O.B. Olutunde, and A.A. Olapeju, 2017. Nutritional composition and heavy metal content of selected fruits in Nigeria. Journal of Agriculture and Environment for International Development, 11 (1): 123-139.

Lenntech, 2004. Water Treatment and Air Purification Water Treatment. Lenntech, Rotterdamseweg, Netherlands. Accessed at: www.excelwater.com/thp/filters/WaterPurification.htm on 22-12- 202020.

McBride, M.B., H.A. Shayler, and H.M. Spliethoff, 2014.Concentrations of lead, Cadmium and barium in urban garden grown vegetables: the impact of soil variables. Environ. Pollut., 194:254-261.

Ming-Ho, Y., 2005. Heavy Metals and Human Health. In Tech, Accessed at: www. cdn.intechweb.org

/pdfs/27687. pdf on22-12-2010.

Mintah, B.K., A.E. Eliason, M. Nsiah, E.M. Baah, E. Hagan, and D.B. Ofosu, 2012. Consumption of fruits among students: A case of Public University in Ghana. African Journal of Food, Agriculture, Nutrition and Development, 12(2):5979-5993.

Mohamed, H.H.A., and M. Khairia, 2012. Assessment of some Heavy Metals in Vegetables, Cereals and Fruits in Saudi Arabian Markets. Egyptian Journal of Aquatic Research, 38: 3137.

Morais, S., F.G. Costa, and M.L. Pereira, 2012. Heavy Metals and Human Health, Environmental Health - Emerging Issues and Practice. In Tech, Accessed at: http://www. intechopen. com/books/environmental on 18-12-2020.

Morelli, J., and R. Greenwood, 2011. Environmental Sustainability and Professional Responsibility. Seventh Environmental Management Leadership Symposium, 12-13 May. 2011, Rochester, NY., 22-24. 
Nabulo, G., C.R. Black, and S.D. Young, 2011. Trace Metal Uptake by Tropical Vegetables Grown on Soil Amended with Urban Sewage Sludge. Environ Pollut., 159: 368-376.

Navas-Acien, A., E. Guallar, E.K. Silbergeld, and S.J. Rothenberg, 2007. Lead Exposure and Cardiovascular Disease: A Systematic Review. Environ. Health Perspect, 115:472-482.

Orisakwe, O.E., J.K. Nduka, C.N. Amadi, D.O. Dike, and O. Bede, 2012. Heavy metals health risk assessment for population via consumption of food crops and fruits in Owerri, South Eastern, Nigeria. Chem Central J., 6:153-1752.

Oyebode, O., D.V. Gordon, A. Walker, and J.S. Mindell, 2014. Fruit and vegetable consumption and all-cause, cancer and CVD mortality: Analysis of Health Survey for England data. Journal of Epidemiology and Community Health. 68(9). DOI: 10.1136/jech-2013-203500.

Prabhat, K.R., S.L. Sang, Z. Ming., F.T. Yiu, and K. Ki-Hyun, 2019. Heavy Metals in Food Crops: Health Risks, Fate, Mechanisms, and Management. Environment International, (125):365-385.

Rahman, M.A., M.M. Rahman, S.M. Reichman, R.P. Lim, and R. Naidu, 2014. Heavy metals in Australian Grown and Imported Rice and Vegetables on Sale in Australia: Health Hazard. Ecotoxicol. Environ. Saf, 100:53-60.

Rai, P.K., 2018. Phyto-remediation of Emerging Contaminants in Wetlands. CRC Press, Taylor \& Francis, Boca Raton, Florida, USA, 248.

Rolls, B.J., J.A. Ello-Martin, and B.C. Tohill, 2014. What can intervention studies tell us about the relationship between fruit and vegetable consumption and weight management? Nutrition Review, 62(1):1-17.

Sajib, M.A.M., M.M. Hoque, S. Yeasmin, and M.H.A. Khatun, 2014. Minerals and heavy metals concentration in selected tropical fruits of Bangladesh. International Food Research Journal, 21(5): 1731-1736.

Satarug, S., H.G. Scoh, A.S. Mary, and A. Donald, 2010. Cadmium. Environmental Exposure and Health Outcomes, 118(2): 182-190.

Säumel, I., I. Kotsyuk, M. Hölscher, C. Lenkereit, F. Weber, and I. Kowarik, 2012.How healthy is urban horticulture in high traffic areas? Trace metal concentrations in vegetable crops from plantings within inner city neighbourhoods in Berlin, Germany. Environ. Pollut., 165:124132.

Seyed, E.M., and R.K. Somashekar, 2008. Heavy Metals and Safety of Fresh Fruits in Bangalore City, India-A Case Study, Kathmandu University Journal of science, engineering and technology, 1(5):17-27.

Singh, A., R.K. Sharma, M. Agrawal, and F.M. Marshall, 2010. Risk assessment of heavy metal toxicity through contaminated vegetables from waste water irrigated area of Varanasi, India. J. Tro.p Ecol., 51(25): 375-387.

Song, D., D. Zhuang, D. Jiang, J. Fu, and Q. Wang, (2015). Integrated Health Risk Assessment of Heavy Metals in Suxian County, South China. Int. J. Environ .Res. Public Health, 12: 7100-7117. United Nations-Habitat, 2004.The State of the World's Cities: Globalization and Urban Culture. UN-HABITAT, Human Settlements Programme, Nairobi.

United State Environmental Protection Agency (USEPA), 2000. Supplementary Guidance for Conducting Health Risk Assessment of Chemical Mixtures. In: Risk Assessment Forum Technical Panel; 2000 [EPA/630/R-00/002].

Wang, Z., J. Chen, L. Chai, Z. Yang, S. Huang, and Y. Zheng, 2011. Environmental Impact and site Specific Human Health Risks of Chromium in the Vicinity of a Ferro-alloy Manufactory. China J Hazard Mater, 190: 980-985.

Wodaje, A.T., 2017. Analysis of Heavy Metal Levels in Some Edible Fruits from Selected Markets in Ethiopia. Journal of Modern Chemistry \& Chemical Technology, 6:2229-6999.

World Commission for Environment and Development (WCED), 1987. Our Common Future. Oxford University Press.

Zaidi, M.I., A. Asrar, A. Mansoor, and M.A. Farooqui, 2005. The Heavy Metal Concentrations along Road Sides' Trees of Quetta and its Effects on Public Health. Journal of Applied Sciences, 5(4): 708-711. 
Zhang, X., T. Zhong, L. Liu, and X. Ouyang, 2015. Impact of Soil Heavy Metal Pollution on Food Safety in China. PLoS One, 10(8):135-182.

Zhou, H., 2016. Accumulation of heavy metals in vegetable species planted in contaminated soils and the health risk assessment. Int. J. Environ. Res. Public Health, 13(3):289. 